\title{
Investigating the Role of Audit Time Pressure on Dividend Quality in Companies Listed in Stock Exchange of Tehran
}

\author{
Investigando o papel da pressão do tempo de auditoria na qualidade de \\ dividendos nas empresas listadas na bolsa de valores de Teerã
}

\author{
Soulmaz Sourmeiy' \\ Ali Mashhadi Khodadadi" \\ Iman Khaki"I \\ Mohammad Taghi Momeni ${ }^{\mathrm{IV}}$
}

\begin{abstract}
The present study investigated the role of audit time pressure on dividend quality in listed companies in Stock Exchange of Tehran. Auditors are often pressured to set time budgets. Due to the increasing importance of audit firms for achieving time budgets as a measure of effectiveness, their difficulties in measuring audit effectiveness, the potential conflict between doing the right things and control costs for high quality audits have intensified. In order to study the aforementioned subject, the statistical population of the audit firms of the member of the Society of Certified Public Accountants within the city of Tehran was determined and the required data were collected from these institutes by random sampling. Durbin-Watson statistic method and correlation with Eviews software were also used to test the research hypotheses. The results indicated that audit time pressure has a significant effect on dividend quality.
\end{abstract}

Keywords: Audit; Stock Exchange; Time Budgets; Time Pressure

\footnotetext{
I Department of Accounting Engineering, Faculty of Engineering, Arak Branch, Islamic Azad University, Arak, Iran - iransourmeiy@aftermail.ir

"Department of Management Engineering, Faculty of Engineering, Arak Branch, Islamic Azad University, Arak, Iran-mashhadi@aftermail.ir

I'Department of Management Engineering, Faculty of Engineering, Arak Branch, Islamic Azad University, Arak, Iran - i.khaki@aftermail.ir

IVDepartment of Accounting Engineering, Faculty of Engineering, Arak Branch, Islamic Azad University, Arak, Iran - momeni@aftermail.ir
} 


\section{Resumo}

O presente estudo investigou o papel da pressão do tempo de auditoria na qualidade dos dividendos nas empresas listadas na Bolsa de Valores de Teerã. Os auditores são frequentemente pressionados a definir orçamentos de tempo. Devido à crescente importância das firmas de auditoria para atingir orçamentos de tempo como uma medida de eficácia, suas dificuldades em medir a eficácia da auditoria, o potencial conflito entre fazer as coisas certas e controlar os custos para auditorias de alta qualidade se intensificaram. Para estudar o assunto acima, foi determinada a população estatística das firmas de auditoria da sociedade da Sociedade de Contadores Públicos Certificados na cidade de Teerã e os dados necessários foram coletados desses institutos por amostragem aleatória. O método estatístico de Durbin-Watson e a correlação com o software Eviews também foram utilizados para testar as hipóteses de pesquisa. Os resultados indicaram que a pressão do tempo de auditoria tem um efeito significativo na qualidade dos dividendos.

Palavras-chave: Auditoria; Bolsa de Valores; Orçamentos de Tempo; Pressão de Tempo 


\section{Introduction}

Professional judgment is of particular importance as auditor time budget pressure seems to have become a common phenomenon in auditing work. The auditor may, on the basis of his judgment, consider some of the steps to be negligible due to time pressures, but may show the opposite in his worksheets. Under the circumstances of the increasing time pressure and the auditor's motivation to continue working with the audit firm, it is important to know whether accountability for the audit performed work leads to an understanding of the costs of reputation and endangers the compliance manipulation in the process of gathering audit evidence, whether there's time pressure or not. Audit quality decreases when auditors are under increasing time pressure. This negative impact remains even among auditors who have more resources. Auditors complete procedures close to the required (or extended) filing deadline, which may jeopardize the quality of the audit to respond the required report. Time budget pressure can have either positive or negative effects. This pressure may force auditors to work hard and as a result to increase efficiency. But if the budgetary pressure is at an anomalistic rate, its negative effects can occur. This pressure may cause auditors to feel stressed and react differently. These reactions can take many forms. They may pay attention to the timing of last year operations and try to keep the timing of current year's operations the same. This is done by performing the task at a specified time. This stress may force them to reduce the quality of auditing in order to comply with the time budget. It is also likely that they will request increased budget time with a positive approach. This stress becomes more severe when time budgeting is considered an important factor in performance evaluation (KARAMI et al., 2016, 9-10).

Dividends quality is one of the important aspects of corporate financial health that is of interest to all users of financial statements. Dividends quality refers to the reported dividends ability in reflecting actual dividends, usefulness in predicting future dividends, as well as the consistency, stability, and non-volatility of reported dividend. Therefore, the criticism of users of such profits is logical and serious, and in economic societies such as Iran that are in the process of privatization, it is vital to measure the true profitability and sound valuation of companies that are fundamentally related to reporting dividend. (DASTGIR et 
al., 2015, 22). Dividend quality is the degree of stability of earnings performance in the coming period. Dividend quality is the probability that future earnings will be sustained. Dividend quality is defined as the ability of profits to represent future earnings. They consider the quality of dividends to be relevant to the intended dividends, which means that the quality of dividend is the degree of integrity that reflects the earnings reported in the dividends report.

Dividends quality is the degree of difference in reported net income from actual earnings. Quality dividends are those that are closer to the value of the company in the long run and contain more information content. Dividend quality is defined as the relationship between accruals and cash flows.

One of the possible reasons for variations in the definitions of dividend quality could be different views of researchers on different aspects of this concept. For this reason, the issue of dividend quality is a complex subject and so far no researcher has been able to provide a comprehensive definition or concept of it (JALILI \& GHEISARI, 2014, 150).

Time pressure is defined as the common constraint on the allocation of resources to perform audit work. In this study, two aspects are considered, including work pressure on time and budgetary pressure. The two concepts are distinct but not necessarily independent of each other (BARZIDEH AND KHAIRALLAHI, 2011, 12).

In this study, we first describe how an external time pressure increase can substantially affect the audit approach and limit the year-end review of the balance of accounts and transactions. We use audit delay to design a continuous scale of audit time pressure and to group companies by the areas in which they are most affected by the timing change. Audit delay is defined as the length of time from the end of a company's financial year to the date of the audit report. Therefore, the main question in this study is that what is the impact of audit time pressure on dividend quality in listed companies in Tehran Stock Exchange?

\section{Theoretical Framework and Research Model}


Measuring dividend quality: Corporate executives use two methods of accrual based dividends management and dividends management based on actual business manipulation. In this study, two measures of voluntary accruals and manipulation of actual activities were used to measure dividends management. Numerous studies have used optional accruals as indicators of dividends management and dividends quality. (A) In this model, the total accruals (TAC) of each period are calculated as described in Model (1). To calculate each year's net accrual of cash flow from operating activities (CFOs), net interest (NI) is deducted:

$\mathrm{TACi}, \mathrm{t}=\mathrm{Nli}, \mathrm{t}-\mathrm{CFO} \mathrm{i}, \mathrm{t}$

Then, using the modified Jones model (Model 2), we estimate the optional accruals of the period (NDACi, $t$ ).

NDACi, t $/$ TAi, $\mathrm{t}-1=\mathrm{a}(1 / \mathrm{TAi}, \mathrm{t}-1)+\mathrm{b}($ NREVi, $\left.\mathrm{t} / \mathrm{TAi}, \mathrm{t}-1)+\mathrm{c}\left(\mathrm{PPEi}_{\mathrm{t}} \mathrm{t} / \mathrm{TAi}, \mathrm{t}-1\right)\right)+\varepsilon_{\mathrm{t}}$ (2)

In the above model: Tai

$\mathrm{t}-1=$ sum of first period assets

$\mathrm{NREVi}, \mathrm{t}=$ Income changes minus changes in accounts receivable

$\mathrm{PPEi}, \mathrm{t}=$ gross property of machinery and equipment

$a, b, c$ are also the model coefficients according to formula (3) and $\varepsilon$ is the model error in year t. To estimate the coefficients of the modified Jones model, the same basic Jones model (Model 3 ) is used.

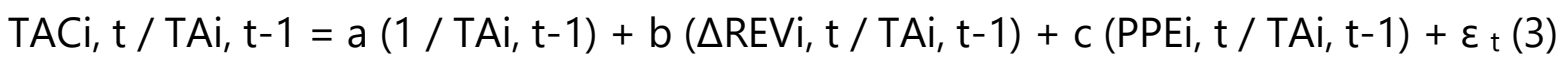

Finally, the amount of optional accruals (DACi, $t$ ) is calculated from the difference of the accruals each year with the estimated non-accruals based on the modified Jones model.

B) The second criterion for measuring the quality of actual dividends is abnormal discretionary spending.

Badraspers (2011) used the following model to estimate the level of discretionary spending, which is also used in this study:

DISEXPt $/$ At- $1=a 0+a 1(1 / A t-1)+\beta(\Delta$ St- $1 /$ At- 1$)+\varepsilon$

A: Total assets 
S: Equals net sales

$\varepsilon=$ residual value as an indicator of dividends quality, taken from Badraspers model (2011).

$\Delta=$ Change of total received accounts

DISEXP: Discretionary spending equal to the sum of $R \& D$ (Research and development) and advertising costs.

Time Pressure: Time pressure is defined as the common limitation on the allocation of resources to perform audit work. Time pressure has been considered in two respects, including the pressure to do the work on time and the budget pressure. The two concepts are distinct, but not necessarily independent of each other. For example, if an auditor had an audit the year before the first changeover deadline, 85 days after the end of the year, the pressure would be the same. The auditor should reduce the audit.

Figure 1 - Conceptual model of research

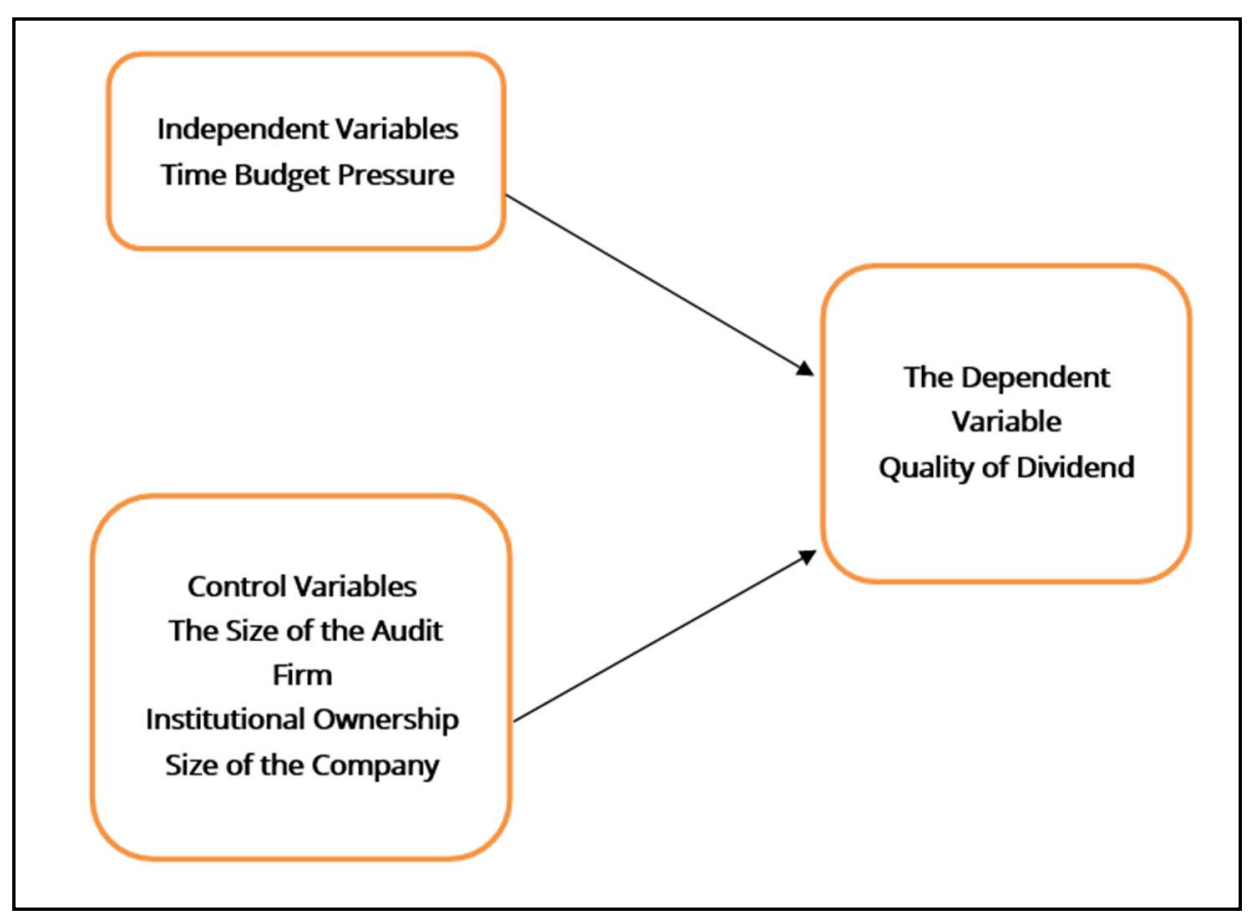

(Malakian and Tavakkolnia, 2014; Tamara et al., 2017)

\subsection{Keyword Definitions}

Time Pressure: Time pressure is defined as the common limitation on the allocation of resources to perform audit work. In this study, two aspects are considered, including work 
pressure on time and budgetary pressure. The two concepts are distinct but not necessarily independent of each other (BARZIDEH AND KHAIRALLAHI, 2011, 12).

Budgetary Pressure: If the budget represents a definite and tangible goal, it has a very strong capacity to motivate. The two main tasks of budgeting are planning and control. The two words planning and control embody a concept, and it provides a systematic, specific way to accomplish responsibilities. From this point of view, it is the task of management to plan and monitor them continuously (MEHRANI \& NAIMI, 2003, 46-44).

Time Budget: It has also been an important management tool in many contemporary audit planning.

Because they provide a basis for estimating and controlling costs, promoting timely completion, evaluating performance, and providing evidence of compliance with appropriate auditing and planning standards and first-time audit supervision. (KARAMI ET al., 2016, 7).

Dividend Quality: SCHOLLER (2004) defines dividend quality as the relationship between accruals and cash flows. One of the possible reasons for variations in the definitions of dividend quality could be different views of researchers on different aspects of this concept. For this reason, the issue of dividend quality is a complex subject and so far no researcher has been able to provide a comprehensive definition or concept of it (JALILI \& GHEISARI, 2014, 148).

\section{Literature Review}

ROBERTSON (2007) has conducted a study on the simultaneous effect of job pressures and budget pressures on concealing audit evidence. The results showed that from the auditors 'point of view, in a day-to-day audit environment, the pressure to perform at the time deadline is of increasing importance, failure to comply with the time deadline and budget undermines the auditors' reputation as an effective person.

GUNDRY et al. (2007) conducted a study titled " Time Budget Pressure, Auditor's Personality Type, and the Incidence of Reduced Audit Quality Practices". The results indicated that they examined the relationship between time budget pressure, auditor 
personality, and incidence two types of audit quality depressing practices prior to an audit step and accepting weak auditor explanations. The findings of the study indicated that there is a significant relationship between time budget pressure and the timely completion of an audit step. There is also a significant relationship between the type of auditor's personality and the occurrence of two types of diminishing audit quality practices. These results indicated that the audit environment is complex and that time budget pressure is only one factor in the deterioration of audit quality. HYATT AND TAYLOR (2013) have conducted a study "on the Effects of Time Budget Pressure and Internationality on Audit Supervisors' Response to Audit Staff False Sign off". In this study, the time budget pressure on audit and targeting of audit team members has been modified and manipulated. The results indicated that audit supervisors often report misstatements when audit staff are working under conditions of low time pressure budget versus high time pressure. Also, audit staff who purposely and deliberately do their job wrong, as well as employees who inadvertently do their job wrong.

GLOVER et al. (2015) conducted a study called "the Effect of Deadline Imposed Time Pressure on Audit Quality". The results indicated that when auditors were under increasing time pressure, the audit quality decreased. This negative impact persists even among auditors who have more resources. The findings of this study indicate that auditors complete procedures near the required filing deadline, which may jeopardize the quality of the audit to meet the required reporting. Recent audits of public-sector auditors also indicate that timely completion of the field audit work is related to audit quality.

PEYTCHEVA (2008) examined the effect of situational and occupational pressures on auditors on the auditor's individual opportunistic behavior and concluded that the aforementioned auditing pressure increased attention to the costs of individual reputation and motivated auditors to perform activities that can compromise the effectiveness of the audit process.

JONES (2008) concluded that in addition to economic motivations and cognitive bias, social and individual factors play an important role in auditor diligence by examining "auditor identity, auditor accountability pressure, and auditor diligence". 


\section{Method}

The present study is an applied research in terms of purpose-based classification. The purpose of applied research is to develop applied knowledge in a particular field. Also, the present study is correlational in terms of method and nature. The purpose of this study is to investigate the impact of audit time pressure on dividend quality in listed companies in Tehran Stock Exchange and correlational research includes all researches that try to find and determine the relationship of different variables using the correlation coefficient. The number of listed companies in Tehran Stock Exchange was 520 companies at the end of 2018. Therefore, according to items 1 to 7, 100 companies were selected as systematic research sample and to test statistical hypotheses, 390 data-year were calculated for each variable of this study and the sampling method is systematic removal. Information gathering has been done using basic corporate information. That is, the information and data required for researching the library in general, using the new approach software, referring to Tehran Stock Exchange and studying the basic financial statements of the companies listed in Tehran Stock Exchange was obtained during the years 2013- 2018.

\section{Findings}

In this part of the study, we examined the research model using data for the studied companies from the years 2013-2018.

(Continue...)

Table 1 - Research Model Estimation

\begin{tabular}{l|c|c|c}
\hline \multicolumn{1}{c|}{ Variable } & Coefficient & T statistics & $\begin{array}{c}\text { Significance } \\
\text { Level }\end{array}$ \\
\hline Time pressure & -0.022601 & -2.049576 & 0.0408 \\
\hline
\end{tabular}




\begin{tabular}{l|c|c|c}
\hline Audit Firm Size & -0.008657 & -0.782019 & 0.4345 \\
\hline Institutional Ownership & -0.107711 & -2.007554 & 0.0451 \\
\hline Firm Size & -0.008072 & -3.203603 & 0.0014 \\
\hline Financial Leverage & -0.022318 & -1.450443 & 0.1475 \\
\hline Assets Return & 0.009128 & 28.46568 & 0.0000 \\
\hline Constant & 0.173727 & 3.027139 & 0.0026 \\
\hline prob(F)=0.000 D.W $=1.95 \quad \overline{\mathrm{R}^{2}}=0.73$ & $\mathrm{R}^{2}=0.73$
\end{tabular}

The coefficient of determination indicates that what percentage of variations of the dependent variable is explained by the independent variable. The closer the number $\mathrm{R}^{2}$ to one, the better the number and type of variables selected to justify the dependent variable in the regression. As it can be observed, the determination coefficient of this estimate is 0.73 and this value indicates that the number and types of selected variables were appropriate to justify the dependent variable in the regression and that the mentioned independent variables were able to justify the dependent variable.

H0. Time pressure has a significant impact on the dividend quality of listed companies in Tehran Stock Exchange.

H 1. Time pressure has no significant effect on the dividend quality of listed companies in Tehran Stock Exchange.

In the studied companies, the study of time pressure variable shows that the probability statistic of this variable is 0.0408 which indicates that time pressure has a significant effect on dividend quality. As a result, the first hypothesis of the study that "time pressure has a significant impact on the dividend quality of listed companies in Tehran Stock Exchange" is accepted.

Therefore, the effect of control variables on dividend quality according to the statistical results, is the following review:

The size of the audit firm has a significant impact on the dividend quality of the companies listed in the Tehran Stock Exchange.

In the studied firms, the audit firm size variable indicates that the probability statistic of this variable is 0.4345 , indicating that audit firm size does not have a significant effect on 
dividend quality. As a result of this research hypothesis that indicated the audit firm size has a significant effect on the quality of dividends of listed companies in Tehran Stock Exchange is rejected.

\section{Conclusion}

In the studied companies, the study of time pressure variable indicated that the probability statistic of this variable is 0.0408 which indicates that time pressure has a significant effect on dividends quality.

As a result, the first hypothesis of the study that stated time pressure has a significant impact on the dividends quality of listed companies in Tehran Stock Exchange will be accepted. This study investigated the effect of time pressures in the audit environment on dividends quality. It is thought that pressures in the audit profession, increased auditors' perceptions of the costs of personal reputation and motivated them to engage in activities that may compromise the impartially effectiveness of the process of collecting and evaluating audited evidence. The studied results of time pressures in this study, by taking into account the accountability background, indicated that accountability for audit work was performed as a common phenomenon in the audit environment and time pressure leads auditors to understand the costs of individual reputation when faced with the subsequent conflicting evidence in the audit. This means that accountability for the performed audit work which can be considered as an incentive for threatening of the dividend quality by auditors under such circumstances. Therefore, according to the results of the research, the following suggestions are discussed:

1. As it is observed, time pressure can increase the probability of concealing subsequent contradictory evidence. Therefore, it is suggested that implicit auditing be conducted to reduce the volume of audit operations for final audit during the financial period. Another way to look at this is to make the end of the financial year for companies different, in terms of the specific characteristics of each company and industry in which they operate. 
2. The results indicated that accountability for the performed audit work can lead to concerns among auditors about individual reputation when faced with subsequent conflicting evidence. Possible solutions for the profession consideration include:

a. Dividing tasks related to selecting and testing sample evidence between different auditors

b. statistical sampling performance and using specialized systems in sampling methods

3. The results indicated that auditors' accountability for audit work leads to the notion of conflict of interest in auditors when confronted with subsequent inconsistent evidence, and consequently concealed evidence in successive decision making situations. Therefore, auditors' adherence to ethical values and performing their duties within those values can lead to a reduction in the pursuit of self-interest. The probability of quality threatening behaviors, and the emphasis on peer review can also be effective by increasing evaluators' awareness.

\section{References}

Barzideh, F. \& Khairallahi, M. Accountability, Timing, and Disclosure of Audit Evidence. Auditing Knowledge, Eleventh Year, No. 45, pp. 4-27, 2012.

Dastgir, M. \& Vahedpour, M. Marking through Voluntary Accruals and Its Impact on Investment in Capital Assets, Accounting Knowledge, No. 30, pp. 114-140, 2016.

Glover, S.M, Hansen, J.C and Seidel, T.A. "The Effect of Deadline Imposed Time Pressure on Audit Quality". SSRN. February 6, 2015.

Gundry, L. time budget pressure, auditor's personality type, and the incidence of reduced audit Quality practices. pacifc Accounting Review, vol 19, 2007.

Hyatt, T.A and Taylor, M. H. "The Effects of Time Budget Pressure and Intentionality on Audit Supervisors' Response to Audit Staff False Sign-Off ", International Journal of Auditing, Vol. 17, Issue 1, pp. 38-53, 2013.

Jalili, S. \& Qheisari, F. Investigating the Relationship between Quality of Dividend and Social Responsibility, Auditing, Volume 14, Number 57, pp147-170, 2016. 
Karami, Gh., Vakilifard, H. \& Mazinani, M. Investigating the Relationship between Time Pressure, Job Complexity, and Audit Effectiveness in the State Accounting Court, Auditing Knowledge, Sixteenth Year, No. 63, pp. 5-33, 2017.

Lambert a., Tamara A. Keith L. Jones., Joseph F. Brazel., D. Scott Showalter. Audit time pressure and earnings quality: An examination of accelerated filings., Accounting, Organizations and Society., pp1-17, 2017.

Malakian, E. \& Tavakkolnia, E. Investigating the Impact of Ethical Culture on Audit Quality Under the Pressure of Time Budgeting, Auditing, Theory and Practice, Vol. 1, No. 1, pp. 2148, 2015.

Mehrani, S. \& Naeemi, M. "Ethical Theory and the Impact of Time Budget Pressure on Independent Auditors' Behavior", University of Tehran Scientific Journals, Volume 10, Number 2, 2004.

Peytcheva, M. "Accountability, Reputation costs, and opportunistic auditor behavior". University of New Jersey, 2008.

Robertson, J.C. Staff Auditor Reporting Decisions under Time Deadline Pressure. Managerial Auditing Journal 22 (4):340-353, 2007. 